Vol. 33(1):13-20

DOI: 10.4217/OPR.2011.33.1.013

\title{
Article
}

\author{
한국 연안역 수질성분들(COD, DIN, DIP, Chlorophyll-a)의 \\ 해역별 농도 특성과 등급화: 통계적 접근 \\ 임동일 $^{{ }^{*}} \cdot$ 최현우 $^{2} \cdot$ 김영옥 $^{1} \cdot$ 정회수 $^{3} \cdot$ 강영실 $^{4}$ \\ 1한국해양연구원 남해연구소 \\ (656-830) 경남 거제시 장목면 장목 1 길 41 \\ 2한구해양연구원 해양자료정보실 \\ 3 한국해양연구원 동북아 EEZ 사업단 \\ (425-600) 경기도 안산시 상록구 해안로 787 \\ 4국립수산과학원 해양환경연구본부 \\ (619-705) 부산광역시 기장군 기장읍 기장해안로 216
}

\section{Concentration Level and Grading of Water Quality Components (COD, DIN, DIP, Chlorophyll-a) in Korean Coastal Waters: A Statistical Approach}

\author{
Dhongil Lim ${ }^{1 *}$, Hyun-Woo Choi ${ }^{2}$, Yong-Ok Kim ${ }^{1}$, Hoi-Soo Jung ${ }^{3}$, and Youg-shil Kang ${ }^{4}$ \\ ${ }^{1}$ South Sea Research Institute, KORDI \\ Geoje 656-830, Korea \\ ${ }^{2}$ Ocean Data and Information Division, KORDI \\ ${ }^{3}$ Research Group for Marine Resource, KORDI \\ Ansan P.O. Box 29, Seoul 425-600, Korea \\ ${ }^{4}$ Marine Environment Research Team, NFRDI \\ Busan 619-705, Korea
}

\begin{abstract}
Comprehensive data collection was carried out between 2001-2006 to investigate the concentration levels of chlorophyll- $a$, nutrients (DIN and DIP), and COD for surface waters of Korean coastal areas. A statistical analysis of these parameters was carried out on the basis of the frequency distribution of their concentration. Furthermore, the numeric grading for chlorophyll- $a$, DIN, DIP, and COD concentrations were derived statistically from the normalized frequency distribution of log-transformed data. The statistical grading clearly reflects the water quality characteristics of three Korean coastal water bodies (Western, Southern and Eastern coastal zones), which indicate common environmental and ecological characteristics. So, this study could provide useful information to set up the guideline for water quality assessment of Korean coasts.
\end{abstract}

Key words : water quality, nutrients, statistical grading, Korean coastal area

\footnotetext{
*Corresponding author. E-mail : oceanlim@kordi.re.kr
} 


\section{1. 서 론}

해양 생태계는 수온, 염분, 용존산소, 광량, 영양염 등 여러 물리-화학적 요인들의 복합적인 상호관계에 의해 조 절되고 유지된다. 이러한 복잡한 많은 요소들 중에서 영양 염은 지역적 그리고 인위적 변동 요소로서 식물플랑크톤 성장에 필수적임과 동시에 그 농도에 따라 해양생태계에 악영향을 유발하는 위험적 오염 요소이기도 하다. 특히 한 반도 주변 연안역(특히 남해 연안역)에서 자주 발생하는 적조와 계절별 저산소 현상(hypoxia/anoxia) 등은 시급히 해결해야할 문제로 제시된다. 이러한 이유로 현재 영양염 의 농도는 해양환경과 생태계 변화에 있어서 국가적 관리 대상으로 인식되고 있다. 최근 세계의 여러 국가들은 장기 적인 모니터링 연구를 통해 영양염 농도와 부유생태계 변 화(특히 일차생산량 증가나 부영양화 발생) 사이의 상관관 계를 파악하고, 이에 근거하여 수질 관리(regional water quality management)를 위한 수질 성분(주로 영양염, 용존 산소, $\mathrm{COD}$, 엽록소)들의 목표 값(objective value)이나 기 준 값(baseline)을 해역별로 설정 - 제시하고 있다(Karydis et al. 1983; Karydis and Coccossis 1990; Ignatiades et al. 1992; EPA 2004; AWQG 2000; EHMP 2008). 일반적으 로 수질성분들 사이, 더 나아가 수질성분과 부유생태계(일 차생산력) 사이에서의 반응은 시간적 지연(time lag) 현상 이 존재한다. 그래서 연속 관측이 아닌, 대부분 계절별 또 는 월별로 이루어지는 현재의 조사를 고려할 때, 수질기준 마련을 위한 성분들 사이의 상호관계를 정확히 파악-이해 하는 데에는 자료의 한계성이 대두된다. 따라서 영양염 농 도에 따른 해양생태계의 반응(특히 일차생산량 변동)을 이 해하고, 이를 토대로 생태학적 관점에서 영양염의 농도 기 준을 설정하기 위해서는 외국에서 진행되고 있는 여러 프 로그램(예, LOICZ, ELOISE 등)처럼 우리나라 또한 연안 력에 주요 표준정점(standard ocean monitoring stations)을 설정하고 이에 대한 다양한 시간 간격의(multitime-scale variation) 중장기적 모니터링 연구가 제안된다.

한편, 미국, 호주 등 여러 국가들에서는 해역별(예, 하구, 만, 항만, 연안 등) 또는 환경 특성별(오염해역 또는 비오 염 해역 등)로 수질 기준 값을 다르게 설정하고, 이를 기 준으로 연별 수질을 평가하고 해역을 관리하고 있다(EPA 2004; AWQG 2000; EHMP 2008). 이러한 수질 기준 값 은 해양생태계 요소들 사이의 복잡한 상호관계를 정확히 이해할 수 있는 각 해역별로 획득된 장기간의 모니터링 자료의 통계적 분석을 통한 기준농도에 근거하고 있다 (Buchanan et al. 2005; EPA 2004; Shrestha and Kazama 2007; NHDES 2008; Kazi et al. 2009). 따라서 해양환경 관리와 평가를 위한 기준 값이 해역에 따라 큰 차이를 보 인다. 미국 $\mathrm{EPA}$ 의 경우, 수질 인자들의 농도를 "Good",
"Fair", "Poor"의 3 등급으로 구분하여 전 연안역을 평가 하고 있으며, 용존무기질소의 경우 동일한 "Good" 등급임 에도 불구하고 걸프 연안(Gulf coast sites)은 $7 \mu \mathrm{M}$ 미만, 서부 연안(west coast sites)은 $35 \mu \mathrm{M}$ 미만 그리고 하와이 (Hawaii)와 플로리다 만(Florida Bay site)은 $3.5 \mu \mathrm{M}$ 미만 으로 해역에 따라 기준 농도를 달리하고 있다(EPA 2007). 이는 해역의 환경 특성과 획득된 자료의 특성에 따라 통 계적 방법으로 배경농도를 설정한 것으로, 우리나라의 경 우도 일반적으로 서해, 남해, 동해 연안역은 강으로부터의 담수 유입량, 조차, 부유물질 농도, 해저지형, 연안역 이용 정도 등에서 서로 크게 차이를 보이는 바, 해역별로 수질 성분들의 특성을 파악할 필요가 있다.

최근까지 우리나라는 해역의 수질관리를 위해 수소이온 농도, 화학적산소요구량, 용존산소, 총질소 및 총인과 같 은 항목에 대한 기준을 설정함으로써 해역의 수질 등급을 해역의 용도에 따라서 I, II, III등급으로 구분하고 있다. 그러나 이러한 값은 설정 기준이 모호할 뿐만 아니라 우 리나라 전 해역에 동일하게 적용되고 있어 해역별 특성을 반영하지 못하고 있어 관리기준으로서의 의미가 분명치 않다. 따라서 연안의 수질관리를 위한 더욱 객관적인 기준 (또는 배경 농도) 마련을 위해서는 우리나라 주변 연안역 에 대한 환경 특성에 따른 해역별 수질 성분(영양염 등)들 의 농도 특성을 정확히 파악-이해하는 것이 선행되어야 할 필요가 있다. 본 연구에서는 지난 6 년간 우리나라 연안 에서 수집된 방대한 양의 자료에 대한 통계정보 분석을 통한 해역별(서해, 남해, 동해 연안역) 수질성분들의 농 도 범위와 분포특성을 파악하고, 상대적 등급화를 시도 하였다.

\section{2. 연구자료 및 방법}

본 연구를 위해 지난 6년(2001 2006년)동안 국립수산 과학원 국가해양환경측정망 사업(http://portal.nfrdi.re.kr/ envirodata)에서 수행된 우리나라 전 연안역의 표층수에서 관측된 엽록소- $a(\mathrm{Chl}-a)$, 용존무기질소(DIN), 용존무기인 (DIP), 화학적산소요구량 $(\mathrm{COD})$ 의 자료를 서해(경기만에 서 진도 연안), 남해(완도 연안에서 기장 연안) 그리고 동 해(감포 연안에서 거진 연안) 연안역으로 구분하여 정 리·분석하였다. 본 연구에서는 제주도 주변의 연안 정점 자료는 제외하였으며, 사용된 전체 자료의 수는 서해 연안 역 1,610 개, 남해 연안역 2,369 개, 동해 연안역 1,611 개이 다. 본 자료에서 매우 높거나 낮게 나타나는 비이상적 값 (abnormal value)으로 평가되는 자료들은 통계분석 자료의 범위에서 제외하였다. 이러한 방대한 양의 자료를 고려할 때, 본 연구에서 제시된 통계량(평균값, 표준편차 등)은 충 분한 의미가 있을 것으로 판단된다. 그러나 이러한 목적을 
위해선 자료의 정규화가 우선 선행되어야 한다. 일반적으 로 해양환경 자료는 특성상 대부분이 정규분포 특성을 보 이지 않기 때문에 자료의 정규화가 필요하며, 이를 위해 로그 변환(Log normal transformation)이나 Box-Cox 변환 (Box-Cox transformation) 등이 사용된다(Ignatiades et al. 1992; Pettine et al. 2007; Shrestha and Kazama 2007; Gowen et al. 2008). 본 연구에서는 정규화를 위해 일반적 이고 간단한 로그 변환 방법을 이용하였으며, 이렇게 변환 된 자료 세트(data set)에 대한 정규분포 정도(normality)를 "Kolmogorov-Smirnov Test" 방법을 이용하여 정규화 정 도를 평가-검증하였다. 본 연구에서의 통계처리는 엑셀 통 계 프로그램(XLSTAT)을 이용하였다.

\section{3. 결과 및 토의}

한국 연안역에서 수질 성분들의 해역별 농도 분포 특성 엽록소- $a$, 용존무기질소, 용존무기인, 화학적산소요구량 의 원 자료(original data)에 대한 기본적 통계량 특성을 해 역별(서해, 남해, 동해 연안역)로 구분하여 Table 1에 제시 하였다. 엽록소- $a$ 의 경우 서해, 남해, 동해 연안역에서 각 각 1,527 개, 2,348 개, 1,533 개의 자료가 이용되었으며, 각

Table 1. Summary of statistical parameters for chlorophyll$a$, DIN, DIP and COD concentrations in western, southern and eastern coastal zones of Korea

\begin{tabular}{clrrr}
\hline & Variable & $\begin{array}{c}\text { Western } \\
\text { coast }\end{array}$ & $\begin{array}{c}\text { Southern } \\
\text { coast }\end{array}$ & $\begin{array}{c}\text { Eastern } \\
\text { coast }\end{array}$ \\
\hline & N & 1527 & 2348 & 1533 \\
$\begin{array}{c}\text { Chlorophyll- } a \\
(\mu \mathrm{g} / \mathrm{l})\end{array}$ & Min. & 0.21 & 0.10 & 0.07 \\
& Max. & 31.03 & 31.31 & 19.35 \\
& Mean & 3.65 & 3.33 & 1.98 \\
& SD & 4.47 & 4.31 & 2.68 \\
\hline & N & 1588 & 2369 & 1611 \\
& Min. & 1.43 & 0.36 & 0.43 \\
DIN & Max. & 308.57 & 133.36 & 93.21 \\
& Mean & 25.35 & 9.69 & 8.63 \\
& SD & 27.71 & 11.78 & 8.85 \\
\hline & N & 1402 & 2106 & 1536 \\
& Min. & 0.19 & 0.13 & 0.03 \\
$(\mu \mathrm{M})$ & Max. & 3.16 & 3.97 & 2.71 \\
& Mean & 0.82 & 0.65 & 0.38 \\
& SD & 0.50 & 0.54 & 0.37 \\
\hline & N & 1610 & 2325 & 1542 \\
$(\mathrm{mg} / \mathrm{l})$ & Min. & 0.32 & 0.30 & 0.20 \\
& Max. & 6.97 & 6.16 & 4.97 \\
& Mean & 1.54 & 1.54 & 1.18 \\
& SD & 0.79 & 0.80 & 0.70 \\
\hline
\end{tabular}

해역별 엽록소의 농도 범위(평균표준편차)는 서해 0.2 $31.0 \mu \mathrm{g} / \mathrm{l}(3.7 \pm 4.5 \mu \mathrm{g} / \mathrm{l})$, 남해 $0.1 \sim 31.3 \mu \mathrm{g} / \mathrm{l}(3.3 \pm 4.3 \mu \mathrm{g} / \mathrm{l})$ 그리고 동해 $0.1 \sim 19.4 \mu \mathrm{g} / 1(2.0 \pm 2.7 \mu \mathrm{g} / \mathrm{l})$ 이다. 엽록소- $a$ 의 평균 농도와 범위가 서해와 남해 연안역에서는 서로 비슷 한 반면, 동해 연안역에서는 상대적으로 낮다(Fig. 1). 용 존무기질소는 해역별로 서해 1,588 개, 남해 2.369 개, 동해 1,611 개의 자료가 이용되었으며, 평균 농도(범위)는 서해 $25.4 \pm 27.7 \mu \mathrm{M}(1.4 \sim 308.6 \mu \mathrm{M})$, 남해 $9.7 \pm 11.8 \mu \mathrm{M}(0.4 \sim$ $133.4 \mu \mathrm{M})$, 동해 $8.6 \pm 8.9 \mu \mathrm{M}(0.4 \sim 93.2 \mu \mathrm{M})$ 이다. 전반적 으로 용존무기질소의 평균 농도, 최대 농도 그리고 변동 폭은 서해 연안역에서 가장 높고, 남해와 동해 연안역으로 갈수록 감소하며, 평균 농도의 경우 남해와 동해 연안역과 비교하여 서해 연안역에서 2배 이상 높았다(Fig. 1). 이러 한 결과는 서해 연안역에 위치한 여러 강으로부터 담수 유입에 의한 높은 오염 부하량에 따른 것으로 해석된다. 용존무기인의 경우 서해, 남해, 동해 연안역에서 각각 1.402 개, 2,106 개, 1,536 개의 자료가 이용되었으며, 평균 농도(범위)는 서해 $0.82 \pm 0.50 \mu \mathrm{M}(0.19 \sim 3.16 \mu \mathrm{M})$, 남해 $0.65 \pm 0.54 \mu \mathrm{M}(0.13 \sim 3.97 \mu \mathrm{M})$, 동해 $0.38 \pm 0.37 \mu \mathrm{M}(0.03 \sim$ $2.71 \mu \mathrm{M})$ 이다. 용존무기인의 농도는 용존무기질소 농도와 달리 서해와 남해 연안역에서는 비슷한 반면, 동해 연안역 에서는 두해역과 비교하여 절반이상 낮게 나타났다. 화학 적산소요구량의 경우 서해, 남해, 동해 연안역에서 각각 1,610 개, 2,325 개, 1,542 개의 자료가 이용되었으며, 각 해 역별 평균 농도(범위)는 서해 $1.5 \pm 0.8 \mathrm{mg} / 1(0.3 \sim 7.0 \mathrm{mg} / \mathrm{l})$, 남해 $1.5 \pm 0.8 \mathrm{mg} / \mathrm{l}(0.3 \sim 6.2 \mathrm{mg} / \mathrm{l})$, 동해 $1.2 \pm 0.7 \mathrm{mg} / 1(0.2 \sim$ $5.0 \mathrm{mg} / \mathrm{l})$ 이다. 화학적산소요구량의 평균 농도와 범위는 서해와 남해 연안역에서 서로 비슷한 반면, 동해 연안역 에서는 다른 수질성분과 유사하게 상대적으로 낮게 나타 났다.

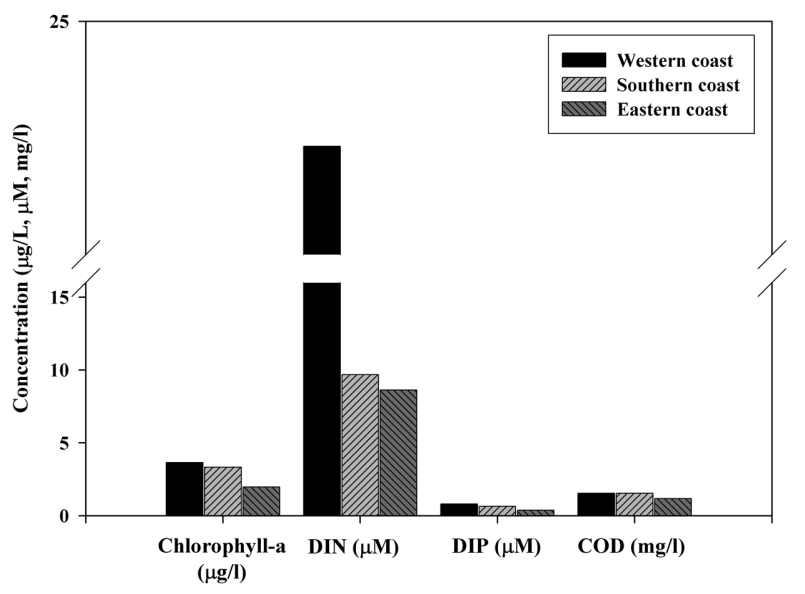

Fig. 1. Comparison of mean values of Chlorophyll-a, DIN, DIP, and COD concentrations in each costal zone 
위와 같이 원 자료의 수질 성분들의 농도 분포 특성을 보면, 엽록소- $a$ 와 용존무기인 농도의 범위와 평균값은 서 해와 남해 연안역은 비슷하거나 서해 연안역에서 약간 높 은 반면, 동해 연안역에서는 다른 두 해역보다 크게 낮 다. 화학적산소요구량의 경우에는 동해 연안역에서 약간 낮은 분포를 보이지만, 전반적으로 세 해역에서 크게 차이 를 보이지 않는다. 그러나 용존무기질소의 농도는 남해와 동해 연안역과 비교하여 서해 연안역에서 2 배 이상 높은 분포를 보인 반면 남해와 동해 연안역에서는 서로 비슷한 농도를 보인다. 이와 같이 각 해역별 수질성분들의 농도 분포 차는 강에 의한 담수 유입량, 갯벌의 발달 정도, 투명 도 그리고 연안 주변에 위치하는 대도시와 산업단지의 발 달 정도 등 여러 환경적 요소들의 차이에 의한 것으로 해 석된다. 특히, 서해 연안역에서 남해와 동해 연안역보다 2 배 이상 높은 농도를 보이는 용존무기질소의 경우 서해 안으로 유입되는 큰 강(한강, 금강, 만경-동진강, 영산강 등)과 소형 하천 그리고 이들 강 주변에 발달하고 있는 대 도시와 산업단지의 발달에 따른 인위적 오염 영향 때문인
것으로 판단된다. 또한 서해 연안역에서는 용존무기질소 와 용존무기인의 농도가 높음에도 불구하고 엽록소- $a$ 의 양은 서해와 남해 연안역에서는 큰 차이를 보이지 않는 다. 남해 연안역에서 상대적으로 높은 엽록소 양은 남해 연안의 만(bay)에서 자주 발생하는 부영양화 또는 적조 현 상과 밀접한 관계가 있는 것으로 추정된다. 한편 동해 연 안역에서의 낮은 영양염 농도는 오염에 의한 영향이 적음 을 의미하며, 이러한 낮은 영양염 농도와 낮은 수온 등으 로 일차생산력(엽록소 양)이 낮은 것으로 해석된다. 따라 서 위에서 제시된 수질자료들의 농도 분포 특성은 우리나 라 연안의 해양환경 특성을 잘 반영하고 있다. 그러나 이 러한 해역별 농도 특성에 대해서는 향후 지형 및 해양환 경 요소 등을 고려한 더욱 세밀한 환경 해역 구분 연구가 필요하다.

\section{수질성분들의 해역별 농도 등급화}

해역별 수질 성분(엽록소- $a$, 용존무기질소, 용존무기인) 들의 원 자료(original data)는 대부분 높은 값에 꼬리를 갖
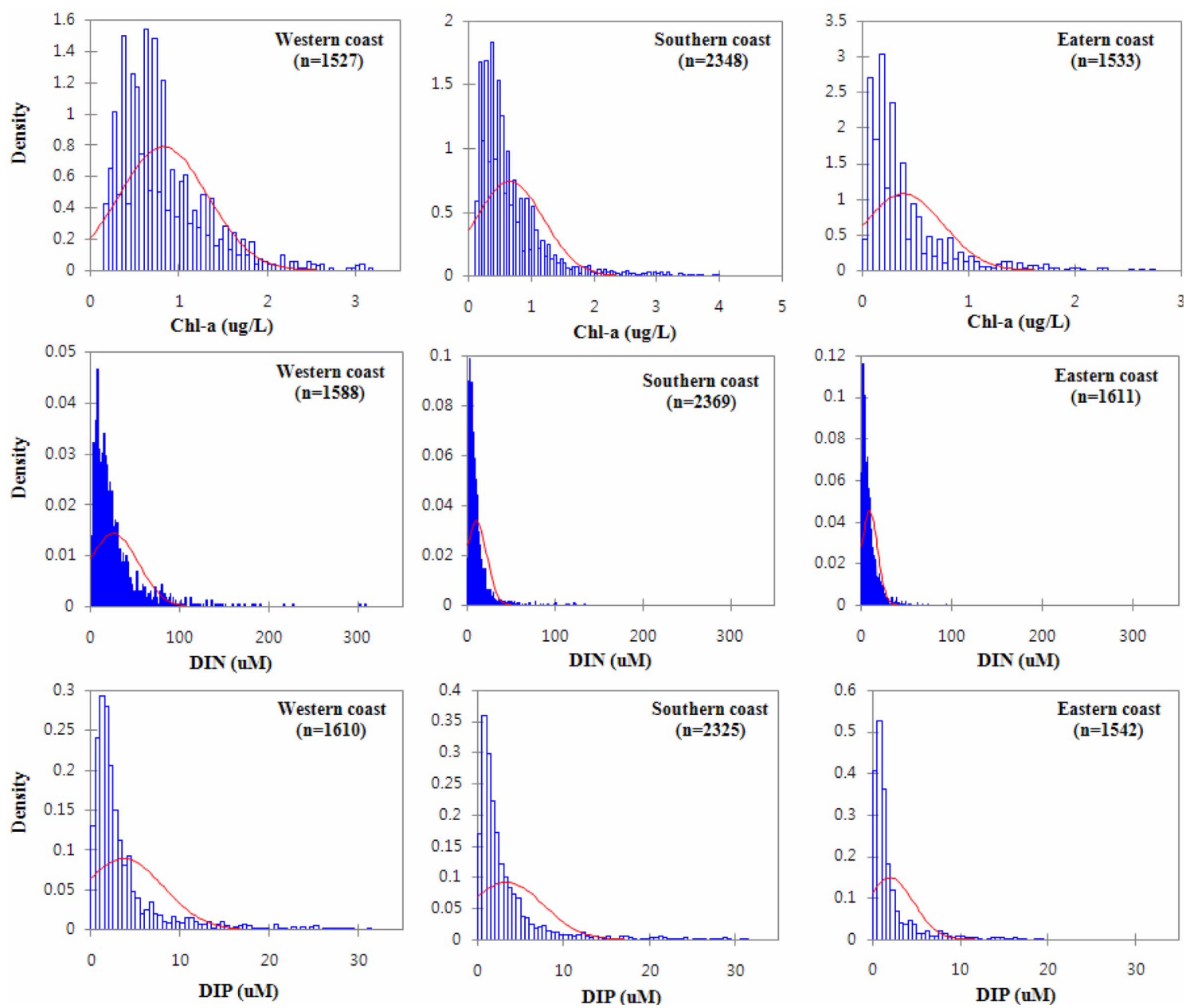

Fig. 2. Frequency distributions of the original data with normal curve superimposed 
Table 2. Statistical parameters including KolmogorofSmirnov value for testing the goodness-of-fit to normality of the $\log$ transformed data

\begin{tabular}{|c|c|c|c|c|}
\hline & Variable & $\begin{array}{c}\text { Western } \\
\text { coast }\end{array}$ & $\begin{array}{c}\text { Southern } \\
\text { coast }\end{array}$ & $\begin{array}{c}\text { Eastern } \\
\text { coast }\end{array}$ \\
\hline \multirow{6}{*}{ Chlorophyll- $a$} & $\mathrm{~N}$ & 1527 & 2348 & 1533 \\
\hline & Min. & -0.68 & -1.00 & -1.15 \\
\hline & Max. & 1.49 & 1.50 & 1.29 \\
\hline & Mean & 0.35 & 0.28 & 0.03 \\
\hline & SD & 0.43 & 0.46 & 0.48 \\
\hline & $\begin{array}{l}\text { Normality } \\
\text { (p-value)* }\end{array}$ & 0.04 & 0.30 & 0.04 \\
\hline \multirow{6}{*}{ DIN } & $\mathrm{N}$ & 1588 & 2369 & 1611 \\
\hline & Min. & 0.15 & -0.45 & -0.37 \\
\hline & Max. & 2.49 & 2.13 & 1.97 \\
\hline & Mean & 1.22 & 0.80 & 0.74 \\
\hline & SD & 0.40 & 0.40 & 0.44 \\
\hline & $\begin{array}{l}\text { Normality } \\
(p-v a l u e)^{*}\end{array}$ & 0.11 & 0.11 & $<0.01$ \\
\hline \multirow{6}{*}{ DIP } & $\mathrm{N}$ & 1402 & 2106 & 1536 \\
\hline & Min. & -0.71 & -0.89 & -1.49 \\
\hline & Max. & 0.50 & 0.60 & 0.43 \\
\hline & Mean & -0.16 & -0.30 & -0.58 \\
\hline & SD & 0.26 & 0.31 & 0.38 \\
\hline & $\begin{array}{l}\text { Normality } \\
(p-v a l u e)^{*}\end{array}$ & 0.02 & 0.01 & $<0.01$ \\
\hline \multirow{6}{*}{ COD } & $\mathrm{N}$ & 1610 & 2325 & 1542 \\
\hline & Min. & -0.49 & -0.52 & -0.70 \\
\hline & Max. & 0.84 & 0.79 & 0.70 \\
\hline & Mean & 0.14 & 0.13 & 0.00 \\
\hline & SD & 0.20 & 0.22 & 0.26 \\
\hline & $\begin{array}{l}\text { Normality } \\
\text { (p-value)* }\end{array}$ & 0.04 & 0.08 & 0.05 \\
\hline
\end{tabular}

*Normality was tested by Kolmogorov-Smirnov statistic method (at 0.05 significance level)

는 양의 왜도(positive skewness) 특성의 빈도분포를 (frequency distribution)보인다(Fig. 2). 이러한 비정규분포 특성은 본 연구에서 사용된 자료들이 자연환경 해역(정 점)과 인위적 오염 영향 해역(정점 또는 관측 값)을 모두 포함하고 있음을 보여준다. 그러나 일반적으로 모집단의 특성을 정확하게 반영하는 통계적 변수들의 값은 자료들 이 정규분포 특성을 가정할 때 그 의미가 있다. Fig. 2에 제시된 것처럼 우리나라 수질 성분들의 원 자료의 분포 특성은 정상적인 정규분포를 가정하기 어렵다. 따라서 이 러한 특성을 갖는 원 자료들의 평균값과 표준편차 등의 통계적 인자들을 이용할 때는 세심한 주의가 필요하다. 이
러한 문제를 해결하기 위해 본 연구에서는 자료의 정규화 를 위해 로그 변환( $\log$ transformation)을 이용하여 원 자 료의 정규성(normality)을 시도하였다. 로그 $(\mathrm{Log})$ 변환된 자료들의 정규분포에 대한 정규성을 파악하기 위해 Kolmogorov-Smirnov Test를 실시하였으며, 통계적 결과를 Table 2에 제시하였다. 엽록소- $a$ 농도의 경우 KolmogorovSmirnov Test의 $p$ 의 값(p-value)이 서해, 남해, 동해 연안 역에서 각각 $0.04,0.30,0.04$ 로 정규분포 $(p$ 의 값이 0.05 이상) 또는 정규분포에 가까운 특성을 갖는다. 용존무기 질소의 경우에도 서해, 남해, 동해 연안역에서 각각 0.11 , 0.11 및 <0.01로, 상대적으로 정규성이 떨어지는 동해를 제외하면 서해와 남해 모두 정규분포 특성을 보인다. 용존 무기인의 경우에는 서해, 남해, 동해 연안역에서 각각 $0.02,0.01,<0.01$ 로 다른 성분들보다 정규분포의 특성이 낮지만, Fig. 3에 제시된 바와 같이 정규분포에 가까운 특 성을 보인다. 화학적산소요구량 또한 $p$ 의 값이 서해 0.04 , 남해 0.08 , 동해 0.05 로, 매우 양호한 정규분포 특성을 가 진 자료로 변환되었음을 알 수 있다. 이러한 로그 변환된 자료들의 정규분포 정도는 빈도분포곡선에서 더욱 가시적 으로 잘 나타난다(Fig. 3). 따라서 원 자료와 다르게 로그 변환된 자료들에 대한 통계분석 결과들은 모집단의 특성 즉, 각 해역별 수질 특성을 잘 반영할 것으로 판단된다. 로 그 변환된 자료에서 엽록소 평균값은 서해와 남해 연안역 에서 각각 $0.35 \pm 0.43$ 와 $0.28 \pm 0.46$ 로 서로 비슷한 반면, 동해 연안역에서는 $0.03 \pm 0.48$ 로 낮다(Table 2). 용존무기 질소는 서해 연안역에서 평균 $1.22 \pm 0.40$ 로 가장 높고, 남 해와 동해 연안역에서는 각각 $0.80 \pm 0.40$ 과 $0.74 \pm 0.44$ 로 비슷하다. 용존무기인의 평균값은 서해와 남해 연안역에 서 각각 $-0.16 \pm 0.26$ 과 $-0.30 \pm 0.31$ 로 비슷한 반면, 동해 연안역에서는 $-0.58 \pm 0.38$ 으로 낮다. 화학적산소요구량의 경우, 서해 $0.14 \pm 0.20$, 남해 $0.13 \pm 0.22$, 동해 $0.00 \pm 0.26$ 으로, 서해와 남해 연안역은 비슷한 반면, 동해 연안역에 서는 다소 낮은 평균값을 갖는다.

본 연구에서는 로그 변환에 의해 정규화된 자료의 평균 (mean)과 표준편차 $(\delta)$ 를 이용하여 우리나라 연안역에 분 포하는 수질성분들의 농도를 4 개의 상대적 등급으로 구분 하였다. Mean $\pm 1 \delta$ 범위는 전체의 약 $67 \%$ 에 해당하는 일 반적 농도 범위(moderate, “보통”), Mean $+1 \delta \sim$ Mean $+2 \delta$ 범위(전체 상위 약 $14 \%$ 영역)는 상대적으로 높은 농도 범 위(high, “높음"), Mean+28(전체 최상위 약 $3 \%$ 영역) 이 상은 매우 높은 농도(very high, "매우 높음")로 등급화 하 였으며, 이와 동일하게 Mean- 1 (전체 하위 약 $17 \%$ 영역) 이하는 낮은 농도(low, “낮음") 범위로 구분하였다. 이러 한 통계적 등급화에서 Mean $\pm 1 \delta$ 범위는 지난 6 년 동안 우리나라 연안역에 가장 일반적으로 분포하는 평균 범위 의 농도로, Mean $\pm 1 \delta$ 범위 이상(또는 이하)은 상대적으로 

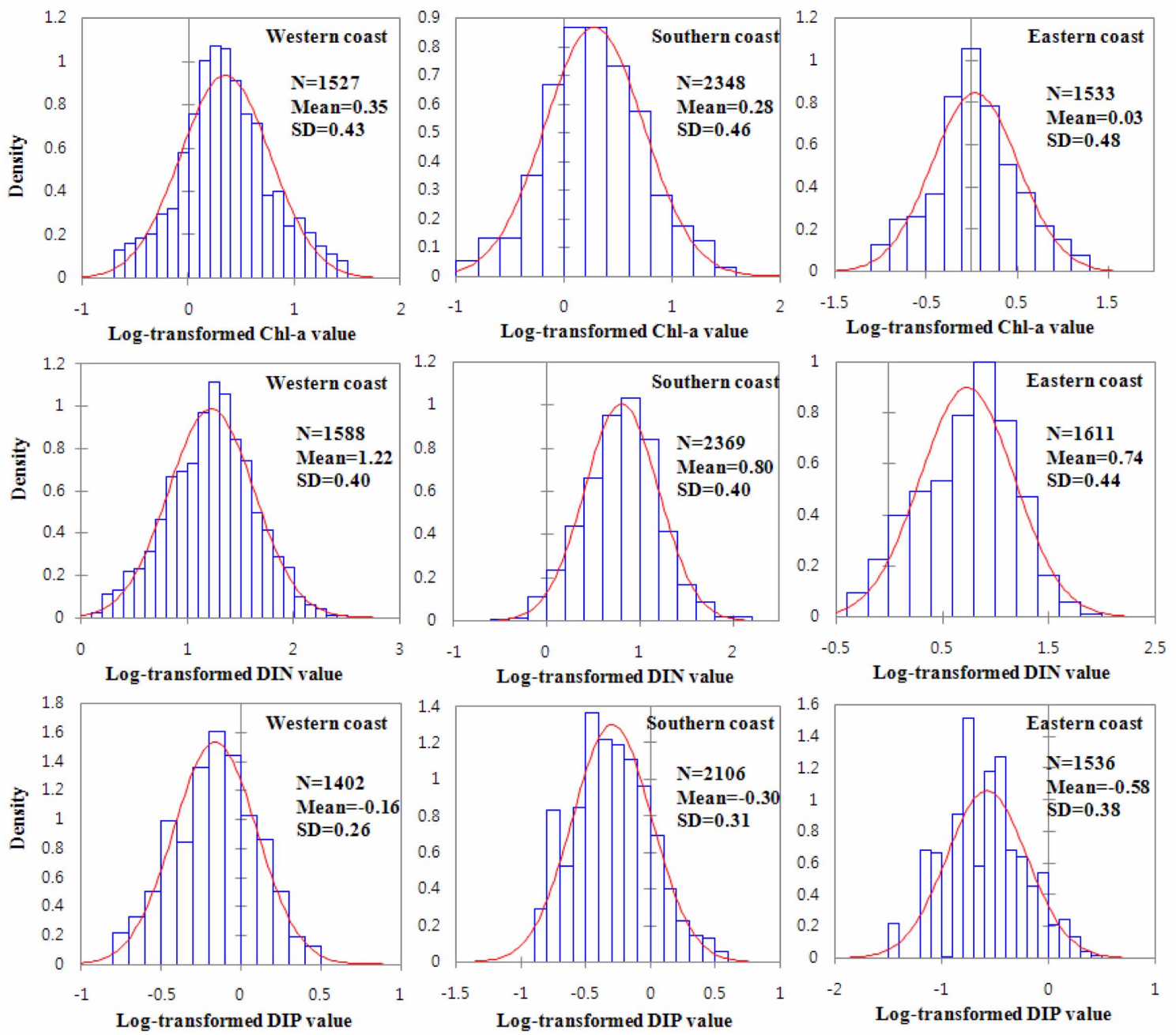

Fig. 3. Frequency distribution of the log-transformed data with the normal curve superimposed

출현 빈도가 매우 낮은 농도 범위로 이해할 수 있다. Table 3은 이와 같이 로그 변화된 자료의 상대적 등급도를 쉽게 이해하기 위해 원 자료의 농도로 재 환산한 우리나 라의 해역별 수질 농도 등급표이다. 연구결과에 따르면 우 리나라 연안역에 분포하는 엽록소- $a$ 의 상대적 등급 기준 값들은 서해와 남해 연안역에서는 비슷하였으나, 동해 연 안역에서는 훨씬 낮게 분류되었다. 엽록소- $a$ 의 "보통 (moderate)" 등급은 서해와 남해 연안역에서 서로 비슷한 약 $0.7 \sim 6.0 \mu \mathrm{g} / 1$ 범위이며, 동해 연안역에서는 상대적으로 낮은 약 $0.4 \sim 3.0 \mu \mathrm{g} / 1$ 범위로 제시된다. "높음(high)" 등급 의 경우 서해와 남해 연안역에서 대략 $6 \sim 16 \mu \mathrm{g} / \mathrm{l}$, 동해 연 안역에서 3 10 $\mu \mathrm{g} / 1$ 범위이다. 서해와 남해 연안역에서는 엽록소- $a$ 의 양이 $16 \mu \mathrm{g} / 1$ 을 넘을 경우 "매우 높음(very high)" 등급으로 분류되며, 전체 시료 중 서해와 남해에서 각각 50 개와 70 개로, 부영양화 또는 적조 발생시에 관측 된 자료들로 추정된다.

용존무기질소의 등급 기준 값은 서해 연안역에서 가장
높게 설정되는 바, "보통(moderate)" 등급의 경우 서해 연 안역에서 7 43 $\mu \mathrm{M}$ 로 높고, 남해와 동해 연안역에서는 각 각 3 16 $\mu \mathrm{M}$ 과 2 15 $\mu \mathrm{M}$ 범위로 비슷하게 낮다. 이러한 해역별 차이는 위에서 언급된 바와 같이 서해안에 위치한 여러 큰 강으로부터 유입되는 많은 양의 인위적 오염물질 공급 때문으로 해석된다. 특히, 한강이 위치한 인천 연안 역과 시화호, 금강이 위치한 군산 연안역의 정점들에서 상 대적으로 용존무기질소 농도가 크게 높았으며, 이러한 이 유로 서해 연안역의 용존무기질소 농도 기준이 상대적으 로 높게 나타난 것으로 해석된다. 따라서 서해 연안역의 경우 인위적 오염 부하량이 많은 한강의 경기만 해역과 금강 주변 해역은 좀 더 세분화된 수질기준 마련이 필요 할 것으로 판단된다. 반면, 남해와 동해 연안역에서의 용 존무기질소 농도 기준은 서로 비슷하게 설정되었다. 한편 용존무기인 경우, “보통(moderate)" 등급의 기준 값이 서 해와 남해 연안역에서 서로 유사하게 높고 $(0.3 \sim 1.3 \mu \mathrm{M})$, 동해 연안역에서 상대적으로 낮게 $(0.1 \sim 0.7 \mu \mathrm{M})$ 설정되었 
Table 3. Statistical classification of chlorophyll-a, DIN, DIP and COD concentrations in the western, southern and eastern coastal areas of Korea

\begin{tabular}{clccc}
\hline & Grade & $\begin{array}{c}\text { Western } \\
\text { coast }\end{array}$ & $\begin{array}{c}\text { Southern } \\
\text { coast }\end{array}$ & $\begin{array}{c}\text { Eastern } \\
\text { coast }\end{array}$ \\
\hline & Low & $<0.8$ & $<0.7$ & $<0.4$ \\
$\begin{array}{c}\text { Chlorophyll- } a \\
(\mu \mathrm{g} / \mathrm{l})\end{array}$ & Moderate & $0.8 \sim 6$ & $0.7 \sim 6$ & $0.4 \sim 3$ \\
& High & $6 \sim 16$ & $6 \sim 16$ & $3 \sim 10$ \\
& Very high & $>16$ & $>16$ & $>10$ \\
\hline & Low & $<7$ & $<3$ & $<2$ \\
DIN & Moderate & $7 \sim 43$ & $3 \sim 16$ & $2 \sim 15$ \\
$(\mu \mathrm{M})$ & High & $43 \sim 107$ & $16 \sim 40$ & $15 \sim 42$ \\
& Very high & $>107$ & $>40$ & $>42$ \\
\hline & Low & $<0.4$ & $<0.3$ & $<0.1$ \\
DIP & Moderate & $0.4 \sim 1.3$ & $0.3 \sim 1.0$ & $0.1 \sim 0.7$ \\
$(\mu \mathrm{M})$ & High & $1.3 \sim 2.3$ & $1.0 \sim 2.1$ & $0.7 \sim 1.5$ \\
& Very high & $>2.3$ & $>2.1$ & $>1.5$ \\
\hline & Low & $<0.9$ & $<0.8$ & $<0.6$ \\
COD & Moderate & $0.9 \sim 2.2$ & $0.8 \sim 2.3$ & $0.6 \sim 1.8$ \\
$(\mathrm{mg} / \mathrm{l})$ & High & $2.2 \sim 3.6$ & $2.3 \sim 3.8$ & $1.8 \sim 3.3$ \\
& Very high & $>3.6$ & $>3.8$ & $>3.3$ \\
\hline
\end{tabular}

다. 화학적산소요구량의 등급 기준은 서해와 남해 연안역 에서 서로 비슷하여, "보통(moderate)"과 "높음(high)" 등 급의 경우 각각 약 $0.8 \sim 2.3 \mathrm{mg} / 1$ 그리고 약 $2.3 \sim 3.8 \mathrm{mg} / 1$ 범위로, 현재 사용하고 있는 수질등급 $\mathrm{II}(1 \sim 2 \mathrm{mg} / 1)$ 은 보통 등급과 그리고 수질등급 $\mathrm{III}(2 \sim 4 \mathrm{mg} / \mathrm{l})$ 은 높은 등급과 잘 일치한다. 동해 연안역의 경우 보통 등급이 $0.6 ~ 1.8 \mathrm{mg} / 1$ 로 서해 그리고 남해와 비교하여 조금 낮으며(Table 3), 이는 동해 연안역이 서해와 남해 연안역과 비교하여 오염 부하량이 상대적으로 낮음을 의미한다.

결론적으로 환경요소(특히 영양염)의 변화와 생태계(특 히 식물플랑크톤) 반응 사이의 관계를 파악할 수 있는 자 료의 부족한 상황에서 이러한 방대한 자료의 통계적 등급 화는 우리나라 연안역에 분포하는 수질 성분들의 농도 특 성을 파악하고, 이해하는데 필요한 기초 자료를 제공할 것 으로 기대된다. 향후에는 염분을 고려한 수질성분(특히 영 양염)변화에 따른 좀 더 세분화된 환경 특성별 또는 권역 별 분석이 필요하며, 이와 함께 여러 연안 표준정점 (standard ocean monitoring stations)에서의 다양한 시간 간격(multiscalarity)의 중장기적 해양환경 모니터링 연구 가 필요할 것으로 판단된다.

\section{4. 결 론}

본 연구에서는 지난 6년간(2001-2006년) 전국 연안역의
표층수에서 수집된 방대한 양의 수질성분(엽록소- $a$, 용존 무기질소, 용존무기인, 화학적산소요구량) 자료에 대한 서 해, 남해, 동해로 구분된 각 연안역별 농도분포 특성이 통 계적으로 분석 되었으며, 이를 토대로 농도들의 상대적 등 급화를 시도하였다. 본 연구에서 제시된 수질성분들의 농 도 등급표는 우리나라 각 연안 해역별 환경특성을 잘 반 영하고 있으며, 향후 오염총량제나 해역오염부하량 등의 연안역 관리를 위한 참고 값(reference value or objective value) 설정에 하나의 기초자료를 제공할 것으로 사료된다.

\section{사 사}

본 자료를 제공해주신 국립수산과학원 관계자 여러분 과 많은 조언을 주신 두 분의 심사위원께 감사드립니다. 본 연구는 한국해양연구원 기본사업(PE98582)과 국토해 양부의 생태계기본조사 사업(PM55842)에 의해 지원되었 습니다.

\section{참고문헌}

AWQG (Australian Water Quality Guidelines) (2000) Australian Water Quality Guidelines for Fresh and Marine Waters. Australian and New Zealand environment and Conservation Council, Canberra, $250 \mathrm{p}$

Buchanan C, Lacouture RV, Marshall HG, Olson M, Johnson JM (2005) Phytoplankton reference communities for Chesapeake Bay and its tidal tributaries. Estuaries 28: 138-159

EHMP (Ecosystem Health Monitoring Program) (2008) Ecosystem Health Monitoring Program 2006-2007 Annual Technical Report. South East Queensland Healthy Waterways Partnership, Brisbane, $162 \mathrm{p}$

EPA (Environmental Protection Agency) (2004) National Coastal Condition Report II. U.S. Environmental Protection Agency, EPA-620/R-03/002. Office of Water, Office of Reserach and Development, Washington, DC, $248 \mathrm{p}$

EPA (Environmental Protection Agency) (2007) National Estuary Program Coastal Condition Report. Environmental Protection Agency. Office of Water, Office of Reserach and Development, Washington, DC, $445 \mathrm{p}$

Gowen RJ, Tett P, Kennington L, Mils DK, Shammon TM, Stewart BM, Greenwood N, Flanagan C, Devlin M, Wither A (2008) The Irish Sea: is it eutrophic. Estuar Coast Shelf Sci 76:239-254

Ignatiades L, Karydis M, Vounatsou P (1992) A possible method for evaluating oligotrophy and eutrophication based on nutrient concentration scales. Mar Pollut Bull 24:238-243 
Karydis M, Ignatiades L, Moschopoulou N (1983) An index associated with nutrient eutrophication in the marine environment. Estuar Coast Shelf Sci 16:339-344

Karydis M, Coccossis H (1990) Use of multiple criteria for eutrophication assessment of coastal waters. Environ Monit Assess 14:1573-2959

Kazi TG, Arain MB, Jamali MK, Jalbani N, Afridi HI, Sarfraz RA, Baig JA, Shah AQ (2009) Assessment of water quality of polluted lake using multivariate statistical techniqus: a case study. Ecotoxicol Environ Safty 72:301-309

NHDES (New Hampshire Department of Environmental Service) (2008) Methodology and assessment results related to eelgrass and nitrogen in the Great Bay Estuary for compliance with water quality standards for the New Hampshire 2008 Section 303(d) List. Watershed
Management Bureau, Concord, NH, WD Doc R-WD08-18, $70 \mathrm{p}$

Pettine M, Casentini B, Fazi S, Giovanardi F, Pagnotta R (2007) A revisitation of TRIX for trophic status assessment in the light of the European Water Framework Directive: application to Italian coastal waters. Mar Pollut Bull 54:1413-1426

Shrestha S, Kazama F (2007) Assessment of surface water quality using multivariate statistical techniques: a case study of the Fuji river basin, Japan. Environ Modell Soft 22:464-475

Received Sep. 29, 2010

Revised Nov. 17, 2010

Accepted Dec. 9, 2010 